\title{
Laboreal
}

Volume 15 N² | 2019

Varia

\section{O processo do reconhecimento da silicose como fenómeno social}

\section{Marianne Lacomblez}

\section{(2) OpenEdition}

1 Journals

Edição electrónica

URL: http://journals.openedition.org/laboreal/15476

DOI: 10.4000/laboreal. 15476

ISSN: 1646-5237

\section{Editora}

Universidade do Porto

\section{Refêrencia eletrónica}

Marianne Lacomblez, «O processo do reconhecimento da silicose como fenómeno social », Laboreal [Online], Volume 15 №2 | 2019, posto online no dia 01 dezembro 2019, consultado o 24 setembro 2020. URL : http://journals.openedition.org/laboreal/15476; DOI : https://doi.org/10.4000/laboreal 15476

Este documento foi criado de forma automática no dia 24 setembro 2020.

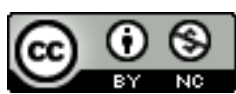

Laboreal está licenciado com uma Licença Creative Commons - Atribuição-NãoComercial 4.0 Internacional. 


\title{
O processo do reconhecimento da silicose como fenómeno social
}

\author{
Marianne Lacomblez
}

1 Três das contribuições publicadas no Datário deste número de Laboreal descrevem e analisam três processos relativos ao reconhecimento médico-legal da silicose como doença profissional: três experiências nacionais, com as suas especificidades e dinâmicas históricas próprias, na Bélgica, no Brasil e em Portugal.

2 A silicose foi considerada, em razão do número de vítimas que ocasionou, como a mais grave doença profissional do século XX. Mas tal ameaça continua a pairar ainda, neste novo século, sobre muitos países, de vários continentes, e particularmente sobre aqueles que hoje são considerados, no quadro do desenvolvimento económico mundial, como países emergentes.

3 O reconhecimento desta “doença dos pós" como doença profissional, conheceu processos longos e, não raras vezes, atribulados. Tal como o ilustram as análises que seguem, a questão central nunca foi exclusivamente de ordem médico-legal, uma vez que a reparação dos danos (e sua dimensão financeira) envolvia uma negociação na qual o social, o económico e o político tinham inevitavelmente um papel determinante. Aliás, o desfecho resultará em geral de dinâmicas de confronto, direto ou indireto, entre os interesses das entidades empregadoras e a salvaguarda de direitos dos trabalhadores.

4 Porém, se o reconhecimento da silicose como doença do e no trabalho constitui uma verdadeira conquista social, mais de que impor a importância das políticas de prevenção e de melhoria das condições e da organização do trabalho, acabará frequentemente por manter, e talvez reforçar, a ideia do seu carácter inevitável no âmbito de determinada atividade económica. Trata-se de questões quase endémicas à problemática das doenças profissionais, que reencontramos se tivermos em atenção o que acontece com a exposição de inúmeros trabalhadores a uma larga variedade de produtos tóxicos (dos quais muitos são cancerígenos) e, por exemplo, à exposição ao amianto - um dos maiores problemas da nossa contemporaneidade. 
5 Nesse último caso, o campo da "saúde no trabalho" se insere claramente no domínio da "saúde pública", realçando assim um dos maiores desafios que se coloca atualmente aos investigadores e aos atores da prevenção. Desejamos, pois, que a leitura destes textos enriqueça a vossa reflexão.

\section{AUTOR}

\section{MARIANNE LACOMBLEZ}

Centro de Psicologia da Universidade do Porto, Faculdade de Psicologia e Ciências da Educação, Universidade do Porto. Rua Alfredo Allen, 4200-135, Porto, Portugal

lacomb@fpce.up.pt 